\title{
Fertility Life Table, Population Parameters and Biotic Potential of Helicoverpa gelotopoeon (Dyar) (Lepidoptera: Noctuidae)
}

\author{
MARÍA I. HERRERO ${ }^{1}$, LUCIANA C. DAMI ${ }^{1}$, SOFÍA V. FOGLIATA ${ }^{1}$, AUGUSTO S. CASMUZ ${ }^{2}$, \\ DANIEL R. SOSA GÓMEZ ${ }^{3}$, GERARDO A. GASTAMINZA² and MARÍA G. MURÚA ${ }^{1}$ \\ ${ }^{1}$ Instituto de Tecnología Agroindustrial del Noroeste Argentino/ITANOA-CONICET, \\ Av. William Cross, 3150, Las Talitas, 4001 Tucumán, Argentina \\ ${ }^{2}$ Estación Experimental Agroindustrial Obispo Colombres/EEAOC, Av. William \\ Cross, 3150, Las Talitas, 4001 Tucumán, Argentina \\ ${ }^{3}$ Embrapa Soja, Rodovia João Strass, s/n, Acesso Orlando Amaral, 86001-970 Londrina, PR, Brazil
}

Manuscript received on March 27, 2018; accepted for publication on June 28, 2018

\begin{abstract}
Helicoverpa gelotopoeon is an endemic pest of South America that affects soybean and other important crops. Life tables are a fundamental tool used to study insect populations, resulting in crucial information for integrated pest management programs. Therefore, the aim of this study was to evaluate the biotic potential and the construction of a life table of this species under laboratory conditions. The biological parameters that showed significant differences between male and female were pupal duration, longevity and life span, which were all longer in duration for males. The net reproductive rate $\left(\mathrm{R}_{0}\right)$ was 95.49 , the mean generation time (T) 37.53, and the instantaneous rate of population increase " $r$ " 0.12 . The population doubling time (DT) was 5.70 days, and the daily finite rate of increase $(\lambda) 1.13$. The maximum rate of population growth occurred in the day 33. Fecundity had two peaks: at days 35 and 37. Gross and net fecundity rate, and the average number of eggs laid per female per day were 565.87, 496.07, and 18.76 respectively. The biotic potential was $2.026 \times 10^{18}$ individuals/female/year. The survivorship curve showed that mortality was high during incubation period and first larval instars, then it declined until the death of last adult. These results provide important information to develop management strategies of H. gelotopoeon in South America.
\end{abstract}

Key words: life cycle, pest management, survival, adult longevity, South American bollworm.

\section{INTRODUCTION}

The South American bollworm, Helicoverpa gelotopoeon (Dyar) (Lepidoptera: Noctuidae), is an endemic species of Argentina, Chile, Brazil, Paraguay and Uruguay (Hardwick 1965, Biezanko et al. 1974, González 1989, Pastrana 2004, Specht et al. 2005, Navarro et al. 2009, Candia 2013).

Correspondence to: María Gabriela Murúa

E-mail:mgmurua@yahoo.com
Helicoverpa gelotopoeon is a polyphagous pest that has been reported feeding on many field and vegetable species such as soybean (Glycine max L.; Fabales: Fabaceae), chickpea (Cicer arietinum L.; Fabales: Fabaceae), cotton (Gossypium hirsutum L.; Malvales: Malvaceae), sunflower (Helianthus annuus L.; Asterales: Asteraceae), corn (Zea mays L.; Poales: Poaceae), alfalfa (Medicago sativa L.; Fabales: Fabaceae), tomato (Solanum lycopersicum L.; Solanales: Solanaceae), line 
(Linum usitatissimum L.; Malpighiales: Linaceae), beans (Phaseolus vulgaris L.; Fabales: Fabaceae) and it also occurs on weeds such us Physalis angulate (L.; Solanales: Solanaceae) (Biezanjo et al. 1974, González 1989, Cork and Lobos 2003, Navarro et al. 2009). Larvae of this species can feed on most plant structures including stems, leaves, flower heads and fruits during their development (SINAVIMO 2018).

Soybean production is substantial in South American countries, including Brazil (114 million tons in 2017, CONAB 2018), Paraguay (10 million tons in 2017, CAPECO 2018) and Uruguay (3.2 million tons in 2017, MGAP 2018). In Argentina, soybean has become the most important cultivated crop, reaching over 18 million ha planted with an average production of 39.5 million tons per year (Bolsa de Cereales 2018). Scalora et al. (2012) reported that $H$. gelotopoeon is capable of producing damage to $81.80 \%$ of the stand of plants of soybean. In addition, there are reports that larval stages of this species can consume $340 \mathrm{~cm}^{2}$ of soybean leaves (Navarro et al. 2009) and that larvae of the final stages can consume up to 15 soybean seeds (Iannone and Leiva 1993). Therefore, the occurrence of this species inflicts significant losses in Argentina.

In addition to its polyphagia, H. gelotopoeon has a great mobility, facultative diapause and a higher reproductive potential, encouraging these characteristics its adaptation to different agricultural ecosystems (Herrero et al. 2017).

The development of an adequate control strategy, with minimal pesticide use, requires basic knowledge on the pest's population dynamics (Pascua and Pascua 2002). Life tables are an important tool for understanding insect population dynamics and to produce basic knowledge for additional studies, such as behavioral analysis, mass rearing, response to control agents, among others. It provides a summary description of age specific mortality rate, survivorship for each developmental stage and reproduction and it is useful in revealing the maximal growth potential of a population. From a pest management standpoint, it is very important to know the most susceptible stage of the pest and therefore the most opportune periods for its control (Kakde et al. 2014).

Currently there are no studies concerning on life table, population parameters and biotic potential evaluations for $H$. gelotopoeon .

Therefore, in order to contribute with helpful information for the management of this pest species, the aim of this study was the construction of a life table and the estimation of population parameters and biotic potential of this species reared in artificial diet at laboratory conditions.

\section{MATERIALS AND METHODS}

\section{INSECT COLLECTIONS}

Adults of H. gelotopoeon were collected in January, 2017 with a light trap in a commercial soybean field in San Agustín locality (26 50'21'’S, 6451'32”W), Tucumán, Argentina. Moths were identified based on the pictorial key of Navarro et al. (2009). Collected adults were placed in cylindrical cages with metal mesh (40 cm high and $20 \mathrm{~cm}$ diameter) and transported to the laboratory. The adults were placed in chambers under controlled conditions (27 $\pm 2^{\circ} \mathrm{C}, 70-75 \% \mathrm{RH}, 14: 10 \mathrm{~L}: \mathrm{D}$ photoperiod) to initiate the experimental colonies (i.e., parental generation). Sampled insects were deposited as voucher specimens in the insect collection of the Sección Zoología Agrícola, Estación Experimental Agroindustrial Obispo Colombres, Tucumán, Argentina.

\section{INSECT REARING}

Adults collected in the commercial soybean field were arranged in five cylindrical oviposition cages (40 $\mathrm{cm}$ high and $20 \mathrm{~cm}$ diameter) with polyethylene bags with approximately 25 females and 25 males per cage. For aeration, both ends of the cage were 
covered with a nylon cloth, which also served as oviposition substrate for females. Each sample was maintained under the abovementioned conditions. When adults died, they were examined using male genitalia to reconfirm the species according to Velasco de Stacul et al. (1969). Rearing procedure and diet composition were according to the methodology described by Herrero et al. (2017).

After establishing a colony for this species, individuals from the second generation (F2) were used for these studies.

\section{BIOLOGICAL AND REPRODUCTIVE PARAMETERS}

From the experimental colony of $H$. gelotopoeon, 241 eggs were randomly selected to analyze development time and survivorship of the different stages (egg, larvae instars, pupa and adult) and the resulting sex ratio.

Each egg was examined separately from each other. Then, in pupal stage, sex was determined according to shape and position of genital openings. This procedure allowed us to evaluate the biological parameters for both sexes, even during their larval stage. Larvae were checked daily to determine the transition (molt) to the next instar by visual observation of the cephalic capsules or mortality.

\section{LIFE FERTILITY TABLE AND POPULATION PARAMETERS}

Cohorts conformed by one virgin female and one virgin male (less than $24 \mathrm{~h}$ old) were conditioned into a cylindrical oviposition cage, similar to those described above, to determine adult longevity and female's reproductive parameters.

Adult survival and female's oviposition were recorded daily to calculate age-specific survival $\left(l_{x}\right.$, number of females alive at age $x$ ) and age-specific fecundity $\left(m_{x}\right.$, number of female offspring produced by females at age $x$ ).

These parameters were used to construct life tables and to estimate population parameters of $H$. gelotopoeon. The population parameters estimated were: net reproductive rate $\left[\left(\mathrm{R}_{0}=\Sigma\left(1_{\mathrm{x}} \mathrm{m}_{\mathrm{x}}\right)\right]\right.$, generational time $\left[\mathrm{T}=\Sigma\left(\mathrm{x} \mathrm{l}_{\mathrm{x}} \mathrm{m}_{\mathrm{x}}\right) / \Sigma\left(\mathrm{l}_{\mathrm{x}} \mathrm{m}_{\mathrm{x}}\right)\right]$, intrinsic rate of increase $\left(r=\operatorname{In} R_{o} / T\right)$, population doubling time $(\mathrm{DT}=\ln 2 / \mathrm{r})$ and finite rate of increase $(\lambda=$ $\left.e^{r}\right)$. The methodologies described by Carey (1993, 1995) were used. A total of 31 cohorts was used for the present assay.

\section{BIOTIC POTENTIAL}

After establishing the biological parameters, the biotic potential (BP) was calculated using the equation described in Silveira Neto et al. (1976): $\mathrm{BP}=(\mathrm{sr} * \mathrm{~d})^{\mathrm{n}}-$ er, where: $(\mathrm{sr})$ sex ratio is number of females divided by number of females plus number of males; (d) viable individuals per female; (n) number of generations per year or 365 days divided by the total lifespan; and (er) environmental resistance. We assumed that there was no er while the insects were reared at the laboratory.

\section{DATA ANALYSIS}

Biological parameters between male and female of $H$. gelotopoeon were compared by Wilcoxon rank-sum test (Lehmann 1975) $(p=0.05)$. All data were analyzed using SPSS version 22.0 (IBM Corp 2013).

\section{RESULTS}

\section{SEXUAL DIFFERENCES IN BIOLOGICAL PARAMETERS}

All adults sampled from Tucumán were identified as H. gelotopoeon (Velasco de Stacul et al. 1969, Navarro et al. 2009).

A total of 95 adults, 52 females and 43 males, were used to determine biological parameters of H. gelotopoeon. The duration of each life stage is presented in Table I. The biological parameters that showed significant differences between male and female were: pupal stage duration ( $W=2043$; $p=0.005)$, adult longevity $(W=1918 ; p=0.004)$ and life $\operatorname{span}(W=2143 ; p=0.008)$, which were all 
TABLE I

Duration in days (mean $\pm \mathrm{SE}$ ) of egg, larval and pupal stages, adult longevity and life span for both sexes of Helicoverpa gelotopoeon.

\begin{tabular}{ccccccc}
\hline Life cycle stages & Female & n & Range & Male & n & Range \\
\hline Egg & $3.2 \pm 0.08 \mathrm{a}$ & 52 & $2-5$ & $3.2 \pm 0.08 \mathrm{a}$ & 43 & $2-5$ \\
& & & & & & \\
Overall larval stage & $13.9 \pm 0.12 \mathrm{a}$ & 52 & $13-17$ & $13.9 \pm 0.15 \mathrm{a}$ & 43 & $12-16$ \\
Pupa & $12.8 \pm 0.17 \mathrm{a}$ & 52 & $10-16$ & $13.6 \pm 0.22 \mathrm{~b}$ & 43 & $12-19$ \\
Adult longevity & $16.8 \pm 0.80 \mathrm{a}$ & 52 & $6-34$ & $19.4 \pm 0.84 \mathrm{~b}$ & 43 & $8-32$ \\
Life span & $46.8 \pm 0.82 \mathrm{a}$ & 52 & $36-64$ & $50.3 \pm 0.72 \mathrm{~b}$ & 43 & $43-62$ \\
\hline
\end{tabular}

Values followed by same letters within a row are not significantly different according to Wilcoxon test $(p<0.05)$.

longer in duration for males (Table I). The progeny reared had a sex ratio of 1.19:1 (F:M). We found not differences in pupal mass $(265.5 \pm 3.41 \mathrm{mg}$ and $265.4 \pm 3.41 \mathrm{mg}$ for females and males respectively) and overall larval stage for both sexes.

\section{LIFE TABLES AND POPULATION PARAMETERS}

The net reproductive rate $\left(\mathrm{R}_{0}\right)$ for $H$. gelotopoeon was 95.49, which indicates that one female could produce, on average, other $95 \pm 0.45$ new females during their lifetime. Because " $\mathrm{R}_{0}$ " value was greater than 1.0, the population of $H$. gelotopoeon under laboratory conditions increased in size. The mean generation time (T) was 37.53, and the instantaneous rate of population increase " $r$ " was 0.12 , indicating that the population was growing at a rate of about 0.12 females/female/day. The population doubling time (DT) was 5.70 days, and the daily finite rate of increase $(\lambda)$ 1.13.

The relation between age-specific fecundity $\left(m_{x}\right)$ and age-specific survival $\left(l_{x}\right)$ is illustrated in Figure 1. The maximum rate of population growth occurred in the day 33 , represented by the first intersection of the specific fecundity and survival lines. Fecundity had two peaks: one at day 35 and the other at day 37 of $H$. gelotopoeon's life cycle.

Gross fecundity rate was 565.87 , net fecundity rate was 496.07 , and the average number of eggs laid per day was 18.76. Daily gross and net fecundity curves are shown in Figure 2.
Considering the survival analysis (Figure 1), out of the 241 eggs reared on artificial diet, only 123 individuals (51.04\%) completed their larval stage and survived to the pupal stage. Among those 123 individuals, only 98 (40\%) reached the adult stage. Males and females had similar survival; out of the total of individuals that reached the adult stage, $49.63 \%$ were females and $50.36 \%$ were males.

The survivorship curve (Figure 1) showed a higher mortality rate during the egg stage and first larval instars. Then, it declined slowly until the death of last adult. This curve of $l x$ resembles the theoretical type III survival curve (Rabinovich 1978).

The life expectancy curve (Figure 2) showed 4 periods of high mortality for this species. The first period was from egg stage to first larval instar, the second and third periods occurred from the second to the third instar and from third to fourth instar, respectively, and the fourth one occurred before pupal stage.

In general, the survival fraction was lower in earlier instars as compared to the later instars, suggesting that the probability of dying was higher in early ages.

\section{BIOTIC POTENTIAL}

Considering a 0.54 sex ratio, no environmental resistance, and the following values for the components of the BP equation, $\mathrm{d}=496.07$ and $\mathrm{n}=7.54$, BP of $H$. gelotopoeon was $2.026 \times 10^{18}$ individuals/female/year. 


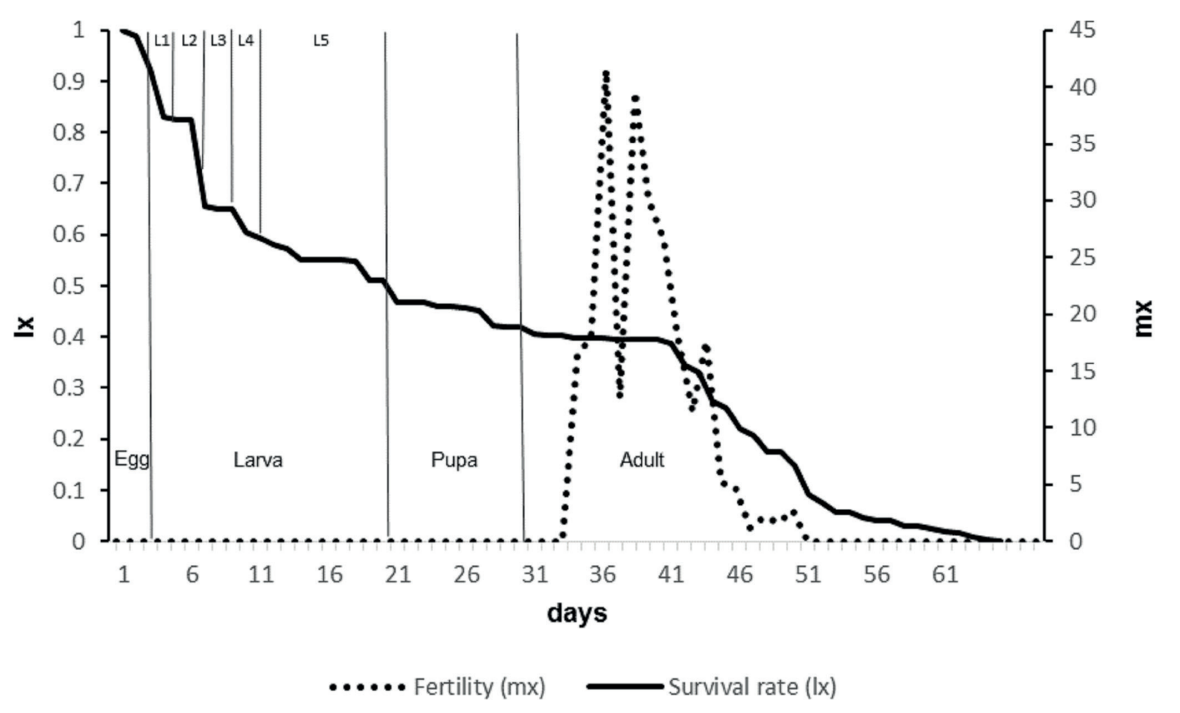

Figure 1 - Relationship between fertility $(\mathrm{mx})$ and survival rate (1x) of Helicoverpa gelotopoeon reared with artificial diet at $25 \pm 2^{\circ} \mathrm{C}, 70-75 \% \mathrm{RH}$ and $14 \mathrm{~L}: 10 \mathrm{D}$.

\section{DISCUSSION}

This study assessed population parameters and biotic potential of an important soybean pest in Argentina. Since there is no published information concerning life table studies of $H$. gelotopoeon to compare our results with, we compared them with data of other species of this genus, with emphasis on $H$. armigera (Hübner).

In our study, males had a longer pupal stage, adult longevity and life span than females. Similar observations were made by $\mathrm{Wu}$ and Wang (2012) for $H$. armigera pupal stage when they reared it at $23^{\circ} \mathrm{C}$. Razmjou et al. (2013) and Naseri et al. (2014) also found that $H$. armigera males had longer adult longevity and total life span than females. According to Slansky (1980), reduction in female's longevity seems to be due to reproduction, caused by the drain of energy during oviposition, reducing the sources available for somatic maintenance.

We also observed that this species has a strong protogyneus emergence, which could be unsuitable for reproductive synchronization under laboratory conditions. Female moths were found to emerge on average two nights earlier than males; these results are similar to those found by Herrero et al. (2017). According to $\mathrm{Wu}$ and Wang (2012), who found the same results for $H$. armigera, this could be attributed to the significantly longer duration of male pupae compared to that of females. However, some authors that worked with other species of Noctuidae such as $H$. armigera, Spodoptera litura (Fabricius) and Pseudaletia unipuncta (Haworth), regard protogyny as a strategy to prevent inbreeding depression (Taylor and Shields 1990, Chen et al. 2014, Li et al. 2014).

The net reproductive rate $\left(\mathrm{R}_{0}\right)$ of females of H. gelotopoeon was lower than that reported for H. armigera by Singh and Yadav 2009, Gomes et al. (2017) and Silva et al. (2017) (332.43; 566 and 303.66 respectively). The intrinsic rate of increase $(r)$ and the finite rate of population increase $(\lambda)$ however, showed similar values when compared with other reports of $H$. armigera (Choudhury et al. 2012, Razmjou 2013, Naseri et al. 2014, Silva et al. 2017). Time elapsed between generations was in general lower than those found for $H$. armigera (Dabhi and Patel 2007, Singh and Yadav 2009, Jha et al. 2014, Gomes et al. 2017) (45.26, 42.62, 46.60 and 47.11 respectively), and the time taken 


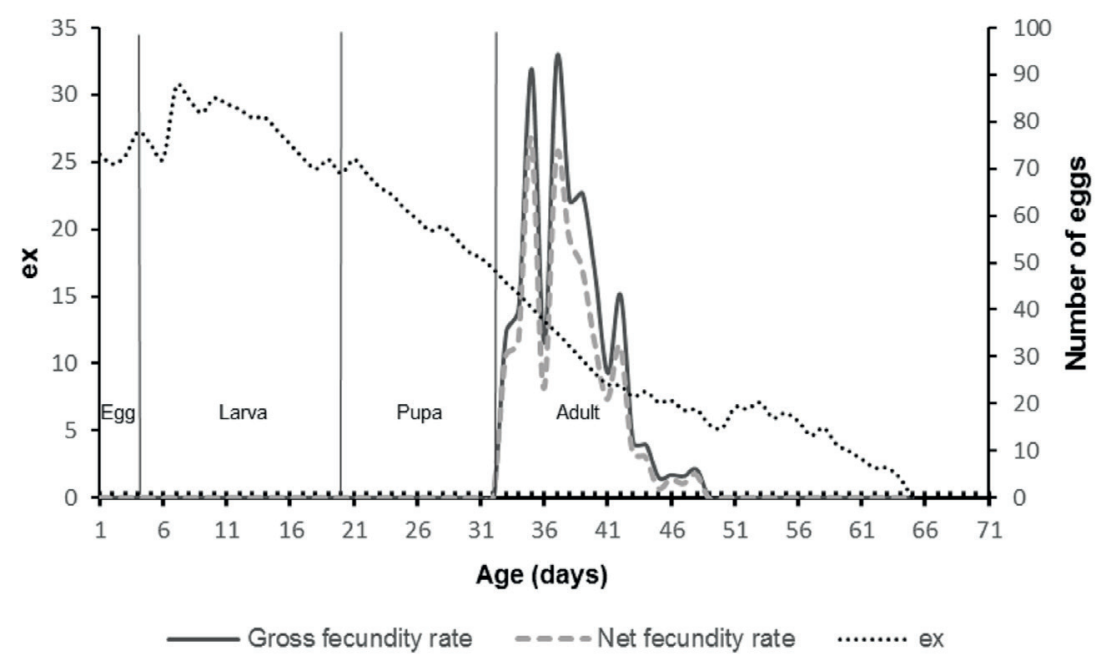

Figure 2 - Life expectancy (ex), daily gross and net fecundity of individuals of Helicoverpa gelotopoeon reared with artificial diet at $25 \pm 2^{\circ} \mathrm{C}, 70-75 \% \mathrm{RH}$ and $14 \mathrm{~L}: 10 \mathrm{D}$.

for the population of $H$. gelotopoeon to double in size (DT) was similar to some reports of $H$. armigera (Choudhury et al. 2012, Razmjou et al. 2013) and Helicoverpa assulta (Guenée) (Wang et al. 2008). These results suggest that this species has a high capacity to increase their populations under controlled rearing conditions and probably under field conditions.

The maximum rate of population growth occurred between days 32 and 34, which was earlier than that found for $H$. armigera by Silva et al. (2017) (days 37 and 39).

The high value of the BP $\left(2.026 \times 10^{18}\right)$ of $H$. gelotopoeon indicates that each female can produce more than 2 trillion of descendants. However, this result is lower than that obtained by Silva et al. (2017) for H. armigera $\left(\mathrm{BP}=2.106 \times 10^{22}\right)$. This differences could be due to the higher fecundity of H. armigera.

The life expectancy curve (ex) indicated the critical ages of mortality. Individuals of $H$. gelotopoeon reared on artificial diet revealed higher mortality at early stages (egg until third larval instar). This result is consistent with Liu et al. (2004), who found that larval mortalities of $H$. armigera were higher between 1-2 instars for all host plants tested, except on cotton. Vargas and Nishida (1980) observed the same trend for Helicoverpa zea (Boddie). Considering the survival curve, our results are similar to those obtained by Jha et al. (2014), who found that only the half of the individuals of $H$. armigera completed their larval stage and survived to pupal stage.

The maximum mean progenies production $\left(m_{x}\right) /$ day was 41.54 females/female on the $35^{\text {th }}$ day of life. This value is lower than that found by Singh and Yadav (2009) who found 70.33 females/female for $H$. armigera.

The mean fecundity of $H$. gelotopoeon reared on artificial diet was 496 fertile eggs/female, which is lower than that observed for H. armigera by Silva et al. 2017, who found values ranging from 592.01 to 914.76 fertile eggs per female. The gap between the curves of total fecundity and total fertility in Figure 2 represents the difference between the number of eggs laid with respect to the number of eggs hatched.

Understanding the demographic parameters of a pest is essential to develop an integrated pest management, given that these parameters provide the population growth rate of a species in the current and next generations (Frel et al. 2003). 
The present study provides novel information about life table parameters and biotic potential of $H$. gelotopoeon. These results are extremely valuable to plan and implement strategies for the future development of Integrated Pest Management programs against this pest in South America.

\section{ACKNOWLEDGMENTS}

We thank to Ing. Lucas Fadda at Estación Experimental Agroindustrial Obispo Colombres (EEAOC) for excellent technical support and assistance in the collection of material. This study was supported by the Agencia Nacional de Promoción Científica de Argentina (ANPCyT) through the Fondo Nacional de Ciencia y Tecnología (FONCyT), Ministerio de Ciencia, Tecnología e Innovación Productiva (MINCyT) (grants PICT/2015 No. 3109), Estación Experimental Agroindustrial Obispo Colombres (EEAOC), Consejo Nacional de Investigaciones Científicas y Técnicas (CONICET), and Consejo de Investigaciones de la Universidad Nacional de Tucumán (PIUNT no. G638/1).

\section{REFERENCES}

BIEZANKO CM, DE RUFFINELLI A AND LINK D. 1974. Plantas y otras sustancias alimenticias de las orugas de los lepidopteros uruguayos. Rev Cent Cien Rurais 4: 107-148.

BOLSA DE CEREALES. 2018. Panorama Agrícola Semanal. Estimaciones Agrícolas. Relevamiento al 31/08/2017. Available at: http://www.bolsadecereales.com.ar. Accessed on March 23, 2018.

CANDIA SM. 2013. Heliothineos en soja: Aspectos biológicos, manejo y control. Agrotecnología 28: 8-14.

CAPECO. 2018. Área de siembra, producción y rendimiento: soja. Available at: http://capeco.org.py/area-de-siembraproduccion-y-rendimiento/. Accessed on May 29, 2018.

CAREY JR. 1993. Applied demography for biologists with special emphasis in insects. Oxford University Press, New York, 206 p.

CAREY JR. 1995. Insect demography. In: Encyclopedia of Environmental Biology, Academic Press, San Diego, p. 289-303.

CHEN C, XIA QW, XIAO HJ, XIAO LAND XUE FS. 2014. A comparison of the life-history traits between diapause and direct development individuals in the cotton bollworm, Helicoverpa armigera. J Insect Sci 14: 1-12.

CHOUDHURY RA, RIZVI PQ AND SATPUTE NS. 2012. Stage specific life table of Helicoverpa armigera (Hübner) on chickpea. Indian J Entomol 74: 310-314.

CONAB. 2018. Série Histórica de Produção de soja. Disponível em: https://www.conab.gov.br/info-agro/ safras/serie-historica-das-safras/item/7666-soja/. Acesso em 29 de maio de 2018.

CORK A AND LOBOS EA. 2003. Female sex pheromone components of Helicoverpa gelotopoeon: first heliothinae pheromone without (Z)-11-hexadecenal. Entomol Exp Appl 107: 201-206.

DABHI MV AND PATEL CC. 2007. Life expectancy of Helicoverpa armigera on chickpea. J Sat Agric Res 5: 1-2.

FREL A, GU H, CARDONA C AND DORN S. 2003. Antixenosis and antibiosis of common beans to Thrips palmi. J Econ Entomol 93: 1577-1584.

GOMES ES, SANTOS V AND ÁVILA CJ. 2017. Biology and fertility life table of Helicoverpa armigera (Lepidoptera: Noctuidae) in different hosts. Entomol Sci 20: 419-426.

GONZÁLEZ RH. 1989. Insectos y ácaros de importancia agrícola y cuarentenaria en Chile. Universidad de Chile, Santiago, p. 137-138.

HARDWICK DF. 1965. The corn earworm complex. Mem Entomol Soc Can 40: 1-247.

HERRERO MI, FOGLIATA SV, VERA AM, CASMUZ AS, SOSA GÓMEZ D, CASTAGNARO AP, GASTAMINZA G AND MURÚA MG. 2017. Biological characterization and mating compatibility of Helicoverpa gelotopoeon (D.) (Lepidoptera: Noctuidae) populations from different regions in Argentina. Bull Entomol Res 108: 108-115.

IANNONE NAND LEIVAPD. 1993. Bioecología, umbrales de acción y control de la isoca bolillera Heliothis gelotopoeon (Dyar) en soja. Carpeta de producción vegetal. INTA, EEA Pergamino, Serie SOJA 7: 1-5.

IBM CORP. 2013. IBM SPSS Statistics for Windows, Version 22.0. Armonk, NY: IBM Corp.

JHA RK, TUAN SJ, CHI H AND TANG LC. 2014. Life table and consumption capacity of corn earworm, Helicoverpa armigera, fed Asparagus, Asparagus officinalis. J Insect Sci 14: 1-17.

KAKDE AM, PATEL KG AND TAYADE S. 2014. Role of Life Table in Insect Pest Management - A Review. IOSRJAVS 7: 40-43.

LEHMANN EL. 1975. Nonparametrics: Statistical Methods Based on Ranks. Holden-Day, Inc. San Francisco, USA, $464 \mathrm{p}$.

LI YY, YU JF, LU Q, XU J AND YE H. 2014. Development and emergence patterns of the tobacco cutworm Spodoptera litura (Lepidoptera: Noctuidae). J Biosci 3: 18-20.

LIU Z, LI D, GONG P AND WU K. 2004. Life table studies of the cotton bollworm, Helicoverpa armigera (Hübner) 
(Lepidoptera: Noctuidae), on different host plants. Environ Entomol 33: 1570-1575.

MGAP - MINISTERIO DE GANADERÍA, AGRICULTURA Y PESCA DE LA REPÚBLICA ORIENTAL DEL PARAGUAY. 2018. Estadísticas agropecuarias (DIEA): Encuesta agrícola “invierno 2017”. Available at: http:// www.mgap.gub.uy/sites/default/files/enc_agricola_ inv2017.pdf/. Accessed on May 29, 2018.

NASERI B, GOLPARVAR Z, RAZMJOU J AND GOLIZADEH A. 2014. Age-stage, Two-sex Life Table of Helicoverpa armigera (Lepidoptera: Noctuidae) on Different Bean Cultivars. J Agr Sci Tech 16: 19-32.

NAVARRO FR, SAINI ED AND LEIVA PD. 2009. Clave pictórica de polillas de interés agrícola, agrupadas por relación de semejanza. $1^{\text {st }}$ ed., INTA EEA Pergamino, Bs As, Argentina, $100 \mathrm{p}$.

PASCUA LT AND PASCUA ME. 2002. Life Table of Cotton Bollworm, Helicoverpa armigera Hübner (Lepidoptera: Noctuidae) in Batac, Ilocos Norte, Philippines. Philipp J Sci 131: 75-89.

PASTRANA JA. 2004. Los lepidópteros Argentinos, sus plantas hospedadoras y otros sustratos alimenticios. Sociedad Entomológica Argentina Ediciones, Buenos Aires, 334 p.

RABINOVICH JE. 1978. Ecología de poblaciones animales. Programa Regional de Desarrollo Científico y Tecnológico, Departamento de Asuntos Científicos, Secretaría General de la Organizacíon de los Estados Americanos, Washington, DC, $114 \mathrm{p}$.

RAZMJOU J, NASERI B AND HEMATI SA. 2013. Comparative performance of the cotton bollworm, Helicoverpa armigera (Hübner) (Lepidoptera: Noctuidae) on various host plants. J Pest Sci 87: 29-37.

SCALORA F ET AL. 2012. Evaluación de diferentes insecticidas para el control de la oruga bolillera, $H$. gelotopoeon Dyar (Lepidoptera: Noctuidae). In: Devani MR, Ledesma F and Sánchez JR (Eds), El cultivo de la soja en el noroeste argentino. Campaña 2011/2012. Publicación Especial EEAOC n ${ }^{\circ} 45$. EEAOC, Las Talitas, Tuc, Argentina, p. 147-151.

SILVA IF, BALDIN EL, SPECHT A, SOSA-GÓMEZ DR, ROQUE-SPECHT VF, MORANDO R AND PAULAMORAES SV. 2017. Biotic potential and life table of
Helicoverpa armigera (Hübner) (Lepidoptera: Noctuidae) from three Brazilian regions. Neotrop Entomol 47: 344351.

SILVEIRA NETO S, NAKANO O, BARBIN D AND VILLA NOVA NA. 1976. Manual de Ecologia dos Insetos. Agronômica Ceres, São Paulo, 419 p.

SINAVIMO. 2018. Sistema Nacional Argentino de Vigilancia y Monitoreo de Plagas Helicoverpa gelotopoeon. Available at: http://www.sinavimo.gov.ar/plaga/helicoverpagelotopoeon. Accessed on March 23, 2018.

SINGH SK AND YADAV DK. 2009. Life table and biotic potential of Helicoverpa armigera (Hübner) on chickpea pods. Ann Pl Protec Sci 17: 90-93.

SLANSKY F. 1980. Quantitative food utilization and reproductive allocation by adult milkweed bugs, Oncopeltus fasciatus. Physiol Entomol 5: 73-86.

SPECHT A, TESTON JA, DI MARE RAAND CORSEUIL E. 2005. Noctuídeos (Lepidoptera: Noctuidae) coletados em quatro Áreas Estaduais de Conservação do Rio Grande do Sul, Brasil. Rev Bras Entomol 49: 130-140.

TAYLOR PS AND SHIELDS EJ. 1990. Development of the armyworm (Lepidoptera: Noctuidae) under fluctuating daily temperature regimes. Environ Entomol 19: 14221431.

VARGAS R AND NISHIDA T. 1980. Life table of the Corn earworm, Heliothis zea (Boddie), in sweet corn in Hawaii. Proc Hawaii Entomol Soc 32: 301-307.

VELASCO DE STACUL M, BARRAL JMAND ORFILA RN. 1969. Taxonomía, especificidad y caracteres biológicos diferenciados del complejo de especies denominadas "oruga del capullo" del algodón, "oruga de la espiga" del maíz, "oruga del brote" del tabaco y "bolillera" del lino. Revista de Investigaciones Agropecuarias, INTA, Bs. As., Rep. Argentina. Serie 5. Patología Vegetal 6: 19-68.

WANG KY, ZHANG Y, WANG HY, XIA XM AND LIU TX. 2008. Biology and life table studies of the oriental tobacco budworm, Helicoverpa assulta (Lepidoptera: Noctuidae), influenced by different larval diets. Insect Sci 15: 569-576.

WU SB AND WANG MQ. 2012. Sexual differences in Helicoverpa armigera (Hübner) (Lepidoptera: Noctuidea) as influenced by photoperiod and temperature. Orient Insect 46: 191-198. 